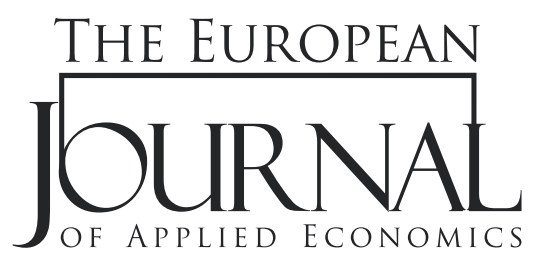

EJAE 2020, 17(1): 20 - 36

ISSN 2406-2588

UDK: 336.744

004.738.5:339.133.5(100)"2015/2019"

DOI: 10.5937/EJAE17-22053

Original paper/Originalni naučni rad

\title{
HERD BEHAVIOUR IN THE CRYPTOCURRENCY MARKET: FUNDAMENTAL VS. SPURIOUS HERDING
}

\section{Chamil W. Senarathne*, Wei Jianguo}

School of Economic,

Wuhan University of Technology, Hubei, China

\begin{abstract}
:
This paper sets out to explore whether the investor herding in the cryptocurrency market induces correlations in cryptocurrency returns using the methodology of Chang et al. (2000) and Galariotis et al. (2015) from a daily data sampling period of $3 / 30 / 2015$ to $5 / 24 / 2019$. The initial regression results show that the cross-sectional absolute deviation of return can only be explained by GSCI oil and gold index return, but no relationship exists between cross-sectional absolute deviation of return and other regression variables, such as return on CCi30, US equity risk premium and US/Euro exchange rate return. The herding regression results under normal market condition show that a strong tendency exists to herd on non-fundamental information that explains cross-sectional absolute deviation of returns. As such, cryptocurrency returns cannot be predicted on the basis of fundamental economic information (e.g., major macroeconomic announcements). Herding on non-fundamental information is found to be more pronounced during an upward-trending period of the market and other than upward-trending period. No signs of herding on fundamental information could be observed under other market conditions. Although the theory suggests that herding on non-fundamental information results in more efficient outcomes, the above findings do not encourage the diversification of traditional assets with cryptocurrency on the basis of low correlation. Since cryptocurrency lacks intrinsic value, the exchange is shown to provide a pseudo-efficient trading platform for speculative investors. Implications for future research are discussed.
\end{abstract}

\section{Article info:}

Received: June 7, 2019

Correction: August 20, 2019

Accepted: August 21, 2019

\section{Keywords:}

herd behavior, cryptocurrency, fundamental information, CASD, portfolio diversification, pseudo efficient, intrinsic value.

\section{JEL Classification:}

G15, G14 


\section{INTRODUCTION}

Herding in financial markets has been a heated debate in the scholarly world over the past two decades. Investor herding is a market phenomenon in which a group of investors simply imitate the actions of others or base their decisions upon the actions of other investors in the market. It can also be a situation in which the trades of a group of investors move in one direction (Nofsinger and Sias, 1999), or investors follow trends in the previous trades, ignoring their initial assessments (Avery and Zemsky, 1998). When herding is present, investor behaviour converges to the average price change pattern of the market (Hirshleifer et al., 2003) which may eventually lead to mutual imitation. Not all investors have the same set of information about security prices at any given point in time, while prices adjust to information as and when the information becomes available to investors. If investors trade without information about the trading securities, price movements will reflect the information variables related to common premiums in the market, while price changes may co-move closely with this premium on average because investors sometimes trade for the sake of trading with speculative profit motives (Senarathne and Jayasinghe, 2017). In such a case, the benchmark for expected payoffs would be the common market expectation (or premium), because there is no security (i.e., firm) specific information ${ }^{1}$.

The term 'herding' is closely associated with 'efficiency'. Herding is one of the critical factors that contribute to market inefficiency. Froot et al. (1992) argue that speculators may choose to study information that is completely unrelated to firms, microeconomic and macroeconomic fundamentals. On the other hand, scholars show that herding on fundamental information (i.e., mimicking fundamental factors) results in inefficient outcomes, whereas herding on non-fundamental information (i.e., mimicking firm-specific factors) leads to efficient market conditions (See Bikhchandani and Sharma 2000). These findings can be effectively observed in markets with instruments (i.e., assets) that have underlying assets. Cryptocurrencies do not have underlying assets to justify whether the trading occurs due to firm-specific (or underlying asset-specific) factors. Although scholars have established efficiency in the cryptocurrency market through their findings (e.g. Urquhart, 2016; Wei 2018), no scholar has attempted to understand the type of efficiency in cryptocurrency trading with reference to any critical factor affecting market efficiency. Moreover, the papers dealing with detecting herding in the cryptocurrency market have so far not attempted to distinguish herding between the fundamental and the spurious (i.e., non-fundamental) in order to understand its impact on market efficiency.

The objective of this paper is to examine the herd behaviour in the cryptocurrency market using the framework of Chang et al. (2000). This paper also attempts to distinguish the herding phenomenon between fundamental and spurious (i.e., non-fundamental) by applying the methodological approach followed by Galariotis et al. (2015). The findings show that there is a strong tendency to herd on nonfundamental information that explains cross-sectional absolute deviation of returns under normal and up-trending market conditions. The paper is organized as follows: Section two provides the econometric framework. Section three provides the statistical properties of the sample data. Section four outlines and discusses the findings. Section five concludes the paper.

\section{LITERATURE REVIEW}

The famous work of Chang et al. (2000) examines the herd behaviour in the stock markets of five countries namely, the USA, Japan, South Korea, Hong Kong and Taiwan, and finds no evidence for herding in the U.S. and Hong Kong markets. However, they find partial evidence for herding in Japanese markets, and significant evidence for herding in the stock markets of South Korea and Taiwan.

1 This is known as common market premium, which is the difference between overall market expectation (i.e., market risk) and the aggregate expectations formed on the basis of firm-specific information. 
Herding has now become a common phenomenon in equity markets, and a number of scholars have observed herd behaviour in equity markets around the world (See, e.g., Peiyuan and Donghui, 2002; Demirer and Kutan, 2006; Tan et al., 2008; Chiang and Zheng, 2010; Demirer et al., 2010; Balcilar et al., 2013; Chen, 2013).

Since the introduction of cryptocurrency (i.e., Bitcoin) in the year 2009, there have been several large literature attempts to understand the nature and characteristics of cryptocurrency. Among them, several papers identify Bitcoin (i.e., the largest cryptocurrency according to market capitalization) as a speculative instrument, although the main purpose of its introduction was to facilitate the settlement of commercial transactions. Along these lines, Yermack (2015), Baek and Elbeck, (2015), Cheah and Fry (2015), Bouoiyour and Selmi (2015), Dyhrberg, (2016), Baur et al. (2017), and Senarathne (2019) establish cryptocurrency (or Bitcoin) as a speculative asset rather than a medium of exchange. The main feature of cryptocurrency is that it does not have an underlying asset and, as such, no reliable method could be used to assess the value of the currency.

Herding phenomenon could be effectively interpreted for financial markets with instruments (i.e., securities) having underlying assets. However, Vidal-Tomás et al. (2018) find evidence for herding during a down-trending market, and observe that the smallest cryptocurrencies tend to herd towards the price change dispersion of the largest ones. Using a rolling window analysis, Bouri et al. (2018a) find that the herd behaviour varies over time in the cryptocurrency market as uncertainty increases. Caporale et al. (2018) examine the degree of predictability of cryptocurrencies, and find that the current value of cryptocurrency is highly positively correlated with its past and future values. They attribute these findings to market inefficiency and the ability of investors to earn arbitrage profits by analyzing the trends in price movements.

Poyser (2018) examines the herd behaviour using Markov-Switching approach, and finds evidence for herding. Derived from a single-factor capital asset pricing model, the framework introduced by Chang et al. (2000) can be meaningfully applied when the asset prices are determined by the information available to investors on the underlying trading assets. In the absence of an underlying asset of a trading currency, investors are either trading for speculative reasons or gambling (Senarathne 2018). Van Wijk (2013) shows that the Bitcoin price is determined mainly by the macroeconomic and financial developments of major economies. However, Cheah et al. (2015) unearth an important fact about Bitcoin in that the fundamental value of Bitcoin prices is zero, and demonstrate that it exhibits speculative bubbles.

The papers reviewed so far have made no attempts to understand what drives herding in the cryptocurrency market. Understanding that would give us an idea about market efficiency (See Bikhchandani and Sharma 2000), because spurious herding may lead to an efficient outcome, while intentional herding may not. In the absence of underlying assets in the cryptocurrency market, it is difficult to establish market efficiency without carrying out an adequate analysis of the market behaviour. Efficiency in the cryptocurrency market cannot simply be assessed by observing the level of correlation between cryptocurrencies and other speculative assets or economic variables, as shown by a number of scholars (See, e.g., Chuen et al., 2017; Guesmi et al., 2019). Instead, additional test procedures must be employed to understand what factually drives efficiency of cryptocurrency. The framework used by Galariotis et al. (2015) provides a meaningful way to analyze the type of herding that can impact cryptocurrency market efficiency.

\section{Econometric Framework}

Chang et al. (2000) introduce a simple framework to detect herd behaviour in financial markets. They use cross-sectional absolute deviation (CSAD) as a proxy for the unobservable expected CSAD. In their work, CSAD is estimated using the average absolute value deviation of each stock relative to the return on an equally-weighted market portfolio. The model assumes a non-linear relationship between CSAD and square of the market return. ${ }^{2}$ Consider the following model in the sense of Chang et al. (2000):

2 Note that this study omits cross-sectional standard deviation (CSSD) method given the inherent limitations associated with its regression (e.g. effect of outliers) 


$$
C S A D_{p t}=\frac{1}{N} \sum_{i=1}^{N}\left|R_{i t}-R_{c c i 30 t}\right|
$$

where $R_{i t}$ is the observed return of cryptocurrency $i$ at time $t$, and CSADN is the total number of cryptocurrencies in the portfolio. The portfolio is formed with Bitcoin, Litecoin, Tether, Nem, Ripple. $C C_{i 30 t}$ is the cryptocurrency market return proxied by the CCi30 cryptocurrency index at time $t$, which was created and has been maintained since $1^{\text {st }}$ January 2017. The base value is set at 100 on $1^{\text {st }}$ January 2015 for the computation of index, and its constituents are maintained by an independent team of mathematicians and fund managers led by a panel of professors and experts (See https://cci30.com/\#statistics for a detailed description on constituents and methodology). 30 cryptocurrencies were chosen based on five main characteristics: 1 . diversified; 2 . replicable; 3 . transparent; 4 . provides in-depth coverage of the entire sector; 5 . presents the best risk-adjusted performance profile possible. The following specification can be used to investigate the general herd behaviour in the cryptocurrency market:

$$
\begin{aligned}
& C S A D_{p t}=a+\gamma_{1} R_{c c i 30 t}+\gamma_{2}\left|R_{c c i 30 t}\right|+\gamma_{3} R_{c c i 30 t}^{2}+u_{t} \\
& u_{t} \backslash\left(u_{t-1}, u_{t-2}, \ldots\right) \sim N\left(0, h_{t}\right) \\
& h_{t}=a+\pi(L) u_{t-1}^{2}+\lambda(L) h_{t-1}
\end{aligned}
$$

where $L$ is the lag operator, and $a$ is the constant of the conditional variance equation, $h_{t}$. Obviously, $a>0$ and $\pi$ and $\lambda$ are the non-negative $\mathrm{ARCH}$ and $\mathrm{GARCH}$ coefficients whose auto-regressive structure requires shocks to volatility to persist over time. Henceforth, coefficients of all mean equations are estimated by the above GARCH variance specification (04), which is unnecessary to repeat under each mean regression. A number of authors document that there is no leverage effect in the cryptocurrency market (see: e.g., Dyhrberg, 2016; Urquhart, 2017; Othman et al., 2019; Senarathne 2019) and, as such, the volatility estimation is limited to the $\operatorname{GARCH}(1,1)$ specification see also Glaser et al., 2014 for a well-received work).

In the presence of herding, the coefficient $\gamma_{3}$ should be negative and statistically significant. The idea is that, if investors tend to follow the aggregate market behavior during periods of large average price movements or during the periods of extreme market conditions, there should be a less-than-proportional increase or even decrease in the cross-sectional absolute return deviation.

Equations (1) and (2) are based on the idea that the market exhibits herding when investors react to information relating to microeconomic or macroeconomic fundamentals, rather than firm-specific information events. In view of this, Galariotis et al. (2015) examine whether the herd behaviour is caused by fundamental information (e.g., fundamental macroeconomic announcements) attached to securities trading. A more appropriate way to distinguish between intentional (or fundamental) herding and spurious herding is to identify whether the herding outcome results in efficient market conditions. Spurious herding may sometimes present due to spurious correlation between the trading behaviour (pattern) of a group of investors and the average trading pattern of the market. This does not necessarily indicate that the investors move towards the market average on fundamental information because there is a common premium in the market (see Senarathne and Jianguo 2018). If herding is present when similar fundamental information is not available to investors, or when investors do not react to fundamental information, this type of herding can be identified as 'spurious,' as opposed to the general idea of herding. This form of herding may lead to an efficient outcome, while intentional or fundamental herding results in a fragile market, excess volatility, and systematic risk. 
In order to estimate CSAD driven by non-fundamental information or the spurious component of price changes, the following method could be used in the pattern of Galariotis et al. (2015). Regress $C S A D$ on some variables could explain cryptocurrency returns.

$$
C S A D_{p t}=\phi+\psi_{1} R P_{t}^{U S}+\psi_{2} G S C I_{t}^{O L L}+\psi_{3} G S C I_{t}^{G O L D}+\psi_{4} C C i 30_{t}+\psi_{5} E X R_{t}+\varepsilon_{t}
$$

where $R P^{U S}$ is the US equity risk premium, which is the value-weighted return of all CRSP firms incorporated in the US and listed on the NYSE, AMEX, or NASDAQ exchanges. GSCI GOLD and GSCI ${ }^{O I L}$ are the S\&P Dow Jones major investable GSCI commodity indices for gold and oil. CCi30 is the cryptocurrency index mentioned above, and EXR is the U.S/Euro exchange rate.

Emulating Galariotis et al. (2015), let the CSAD driven by non-fundamental information be estimated by the following equation:

$$
\begin{aligned}
& C S A D_{p t}^{\text {NONFUND }}=\varepsilon_{t} \\
& C S A D_{p t}^{\text {FUND }}=C S A D_{p t}-C S A D_{p t}^{\text {NONFUND }}
\end{aligned}
$$

Herding under fundamental and non-fundamental information could be estimated by the following equations:

$$
\begin{aligned}
& C S A D_{p t}^{F U N D}=a+\gamma_{1} R_{c c i 30 t}+\gamma_{2}\left|R_{c c i 30 t}\right|+\gamma_{3} R_{c c i 30 t}^{2}+u_{t} \\
& C S A D_{p t}^{N O N F U N D}=a+\gamma_{1} R_{c c i 30 t}+\gamma_{2}\left|R_{c c i 30 t}\right|+\gamma_{3} R_{c c i 30 t}^{2}+u_{t}
\end{aligned}
$$

In the presence of herding, coefficient $\gamma_{3}$ should be negative and statistically significant. It is clear that the cryptocurrencies do not have underlying assets. However, a number of scholars have shown that it is driven by macroeconomic fundamentals (see especially van Wijk 2013). Another section of scholars show that the cryptocurrency price changes are random and, as such, the prices are driven by random information events (see section 1 literature). In the absence of an underlying asset, this random information may include cryptocurrency-specific events, for example, ICO project, trading restrictions, frauds, hacking, trading suspension, or restrictions on cash withdrawal, etc.

The literature shows that herding is more intensive when the markets are on the uptrend (see, e.g., Ouarda et al., 2013; Litimi et al., 2016; BenSaïda 2017). A dummy variable $D_{t}^{u p}$ is introduced at time $t$, which takes the value 1 for all positive observations during the sampling period, or zero otherwise. The following herding regression specification captures the magnitude of investor herding under upwardtrending market condition:

$$
\begin{aligned}
& C S A D_{p t}^{F U N D}=a+\gamma_{1}\left(1-D^{u p}\right) R_{c c i 30 t}+\gamma_{2} D^{u p} R_{c c i 30 t}+\gamma_{3}\left(1-D^{u p}\right) R_{c c i 30 t}^{2}+\gamma_{4} D^{u p} R_{c c i 30 t}^{2}+v_{t} \\
& C S A D_{p t}^{N O N F U N D}=a+\gamma_{1}\left(1-D^{u p}\right) R_{c c i 30 t}+\gamma_{2} D^{u p} R_{c c i 30 t}+\gamma_{3}\left(1-D^{u p}\right) R_{c c i 30 t}^{2}+\gamma_{4} D^{u p} R_{c c i 30 t}^{2}+v_{t}
\end{aligned}
$$


Coefficient $\gamma_{4}$ should be negative and statistically significant if the investor herding is more pronounced when the market is up, rather than down or neutral. If the herding is more intensive during periods other than up-trending market, the coefficient $\gamma_{3}$ should be statistically significant and negative.

Scholars have also shown that herding is more pronounced in crisis and bullish periods (see Bikhchandani and Sharma 2000; Bowe and Domuta 2004; Hwang and Salmon 2004; Philippas et al., 2013; Yao et al., 2014; Galariotis et al., 2015; Bekiros et al., 2017). As such, dummy variables $D^{\text {bullish }}$ and $D^{\text {crisis }}$ are introduced, which take value 1 during the period of the bullish market (the largest bullish cluster) from $3 / 15 / 2017$ to $1 / 05 / 2018$, and during the period of crisis (the largest crisis cluster) from $1 / 07 / 2018$ to $12 / 05 / 2018$, respectively, or otherwise zero. The following two separate regressions detect the herd behavior during bullish and crisis periods of the market:

$$
\begin{aligned}
& C S A D_{p t}^{F U N D}=a+\gamma_{1}\left(1-D^{\text {bullish }}\right) R_{\text {cci30t }}+\gamma_{2} D^{\text {bullish }} R_{\text {cici30t }}+\gamma_{3}\left(1-D^{\text {bulish }}\right) R_{\text {cici3ot }}^{2}+\gamma_{4} D^{\text {bullish }} R_{\text {cci3ot }}^{2}+v_{t} \\
& C S A D_{p t}^{\text {NONFUND }}=a+\gamma_{1}\left(1-D^{\text {bullish }}\right) R_{c c i 30 t}+\gamma_{2} D^{\text {bllish }} R_{c c i 30 t}+\gamma_{3}\left(1-D^{\text {bulish }}\right) R_{c c i 30 t}^{2}+\gamma_{4} D^{\text {bullish }} R_{\text {cii30t }}^{2}+v_{t} \\
& C S A D_{p t}^{F L N D}=a+\gamma_{1}\left(1-D^{c r i s i s}\right) R_{c c i 30 t}+\gamma_{2} D^{c r i s i s} R_{c c i 30 t}+\gamma_{3}\left(1-D^{c r i s i s}\right) R_{c c i 30 t}^{2}+\gamma_{4} D^{c r i s i s} R_{c c i 30 t}^{2}+v_{t} \\
& C S A D_{p t}^{\text {NONFUND }}=a+\gamma_{1}\left(1-D^{\text {crisis }}\right) R_{c c i 30 t}+\gamma_{2} D^{\text {crisis }} R_{c c i 30 t}+\gamma_{3}\left(1-D^{\text {crisis }}\right) R_{c c i 30 t}^{2}+\gamma_{4} D^{\text {crisis }} R_{c c i 30 t}^{2}+v_{t}
\end{aligned}
$$

Similarly, if the herding is more pronounced under bullish or crisis market conditions, the coefficient $\gamma_{4}$ should be negative and statistically significant. If the herding is more intensive during periods other than bullish or crisis market periods, coefficient $\gamma_{3}$ should be negative and statistically significant.

Market volatility and trading activities are highly correlated, and this induces market participation and active trading (Darrat and Rahman 1995; Gallo and Pacini, 2000). A number of scholars demonstrate that investors tend to herd more when the market is highly volatile (see, e.g., Dennis and Strickland 2002; Gleason et al., 2004; Gabaix et al., 2006; Holmes et al., 2013). A dummy variable $D^{\text {volatility }}$ is introduced, which takes the value 1 when the volatility of CCi30 index (i.e., market volatility) return exceeds the average market volatility of the sampling period. The average market volatility can easily be computed from the following $\mathrm{GARCH}(1,1)$ volatility estimates by Eviews:

$$
\begin{aligned}
& R_{c c i 30 t}=c+u_{t} \\
& u_{t} \mid\left(u_{t-1}, u_{t-2}, \ldots\right) \sim N\left(0, h_{t}\right) \\
& h_{t}=a+\pi(L) u_{t-1}^{2}+\lambda(L) h_{t-1} \\
& C S A D_{p t}^{F U N D}=a+\gamma_{1}\left(1-D^{\text {vilatility }}\right) R_{c c i 30 t}+\gamma_{2} D^{\text {vilatility }} R_{c c i 30 t}+\gamma_{3}\left(1-D^{\text {vilatility }}\right) R_{c c i 30 t}^{2}+\gamma_{4} D^{\text {vilatility }} R_{c c i 30 t}^{2}+v_{t} \\
& C S A D_{p t}^{\text {NONFUND }}=a+\gamma_{1}\left(1-D^{\text {vilatility }}\right) R_{\text {cci30t }}+\gamma_{2} D^{\text {vilatility }} R_{\text {cci30t }}+\gamma_{3}\left(1-D^{\text {vilatitity }}\right) R_{\text {cci30t }}^{2}+\gamma_{4} D^{\text {vilatility }} R_{\text {cci30t }}^{2}+v_{t}
\end{aligned}
$$


If herding is more pronounced during high market volatility periods, the coefficient $\gamma_{4}$ should be statistically significant and negative. The coefficient $\gamma_{3}$ should be negative and statistically significant, if herding is more intensive in periods other than high volatility periods.

\section{Data and Sample}

The S\&P GSCI commodity indices data are obtained from S\&P Dow Jones Indices LLC (available at https://us.spindices.com) and the US/Euro exchange rate data are available on the Federal Reserve Bank of St. Louis webpage (available at https://fred.stlouisfed.org). US equity risk premium data are obtained from the data library (MBA portal) of Kenneth R. French (http://mba.tuck.dartmouth.edu/ pages/faculty/ken.french/index.html). The cryptocurrency index CCi30 data were downloaded from the webpage www.cci30.com (available at ttps://cci30.com/). Readers are advised to visit the webpage above for a detailed description about the computation and its constituents. The cryptocurrency price data are obtained from the webpage https://coinmarketcap.com. The sample covers 1,048 daily observations from the period $3 / 30 / 2015$ to $5 / 24 / 2019$. The following steps were followed in processing the data and generating the final outcome. The relevant data are first downloaded from the respective websites and double-checked for accuracy before the return series is generated for each selected cryptocurrency, Bitcoin, Litecoin, Tether, Nem, Ripple (https://coinmarketcap.com), and other assets. The sample is drawn from the top twenty cryptocurrencies ranked by market capitalization. Since most of the cryptocurrencies were launched very recently, priority was given to the date of launch, in addition to the market capitalization, in order to cover a sufficient amount of observations. When portfolio returns are computed, equally-weighted average returns were considered. Once the returns are generated, regressions are run on Eviews statistical software. The raw data used for the research can be reached at http://dx.doi.org/10.17632/k32dph9hjc.1. The correlations among regression variables and the descriptive statistics of the sample data are as follows:

Table 1 - Correlation Matrix of Regressors

\begin{tabular}{lcccccccccc}
\hline Variable & PR $^{\text {US }}$ & GSCI $^{\text {OIL }}$ & GSC $^{\text {GOLD }}$ & $\mathbf{R}_{\text {cci30t }}$ & $\left|\mathbf{R}_{\text {cci30t }}\right|$ & EXR & $\mathbf{D}^{\text {up }}$ & $\mathbf{D}^{\text {bullish }}$ & $\mathbf{D}^{\text {crises }}$ & D $^{\text {volatility }}$ \\
\hline PR $^{\text {US }}$ & 1 & 0.334 & -0.114 & 0.066 & -0.072 & -0.077 & 0.017 & 0.020 & -0.025 & -0.014 \\
\hline GSCI $^{\text {OIL }}$ & 0.334 & 1 & 0.033 & 0.026 & -0.057 & 0.029 & -0.003 & 0.021 & -0.019 & 0.028 \\
\hline GSC $^{\text {GOLD }}$ & -0.114 & 0.033 & 1 & 0.050 & 0.065 & 0.425 & 0.035 & 0.023 & -0.022 & 0.015 \\
\hline $\mathbf{R}_{\text {ci30t }}$ & 0.066 & 0.026 & 0.050 & 1 & -0.033 & 0.013 & 0.656 & 0.140 & -0.144 & 0.029 \\
\hline $\mathbf{R}_{\text {cci30t }} \mid$ & -0.072 & -0.057 & 0.065 & -0.033 & 1 & 0.040 & -0.003 & 0.188 & 0.151 & 0.303 \\
\hline EXR & -0.077 & 0.029 & 0.425 & 0.013 & 0.040 & 1 & 0.033 & 0.054 & -0.029 & 0.001 \\
\hline $\mathbf{D}^{\text {up }}$ & 0.017 & -0.003 & 0.035 & 0.656 & -0.003 & 0.033 & 1 & 0.123 & -0.123 & -0.002 \\
\hline $\mathbf{D}^{\text {bullish }}$ & 0.020 & 0.021 & 0.023 & 0.140 & 0.188 & 0.054 & 0.123 & 1 & -0.261 & 0.242 \\
\hline $\mathbf{D}^{\text {crises }}$ & -0.025 & -0.019 & -0.022 & -0.144 & 0.151 & -0.029 & -0.123 & -0.261 & 1 & 0.308 \\
\hline $\mathbf{D}^{\text {volatility }}$ & -0.014 & 0.028 & 0.015 & 0.029 & 0.303 & 0.001 & -0.002 & 0.242 & 0.308 & 1 \\
\hline
\end{tabular}

As Table 1 reports, the correlations among regression variables are very low. The highest correlation is recorded at 0.656 and the lowest is -0.001 . Crisis dummy, absolute market return, and up-dummy are negatively correlated with most of the other variables. In addition to the abovementioned variables, all other variables are mostly positively correlated with each other. Since the reported correlations are considerably low, the cryptocurrency pricing and herding regressions are free from multicollinearity problem. 
Table 2 - Descriptive Statistics of Sample Data

\begin{tabular}{|c|c|c|c|c|c|c|c|}
\hline Variable & Mean & Med. & Max. & Min. & $\mathrm{JB}$ & $\mathrm{ADF}$ & Q (20) \\
\hline $\mathrm{CSAD}_{\mathrm{pt}}$ & 0.033 & 0.021 & 0.218 & $1.7 \mathrm{E}-05$ & 1410.72 & -12.37 & 792.64 \\
\hline $\operatorname{CSAD}_{\mathrm{pt}}^{\mathrm{FUND}}$ & 0.025 & 0.024 & 0.045 & 0.013 & 1124.6 & -34.79 & 27.31 \\
\hline $\mathrm{CSAD}_{\mathrm{pt}}^{\text {NONFUND }}$ & 0.008 & -0.004 & 0.195 & -0.032 & 1441.62 & -12.33 & 786.96 \\
\hline $\mathbf{P R}^{\mathrm{US}}$ & $3.9 \mathrm{E}-04$ & 0.001 & 0.051 & -0.040 & 702.55 & -32.24 & 34.96 \\
\hline GSCI $^{\text {OIL }}$ & $1.8 \mathrm{E}-04$ & 0.001 & 0.101 & -0.080 & 168.68 & -35.59 & 26.49 \\
\hline GSCI $^{\text {GOLD }}$ & $8.0 \mathrm{E}-05$ & $-1.2 \mathrm{E}-04$ & 0.046 & -0.034 & 422.21 & -33.61 & 25.08 \\
\hline $\mathbf{R}_{\mathrm{cci} 30 \mathrm{t}}$ & 0.004 & 0.004 & 0.196 & -0.292 & 1073.6 & -31.55 & 58.76 \\
\hline$\left|\mathbf{R}_{\text {cci30t }}\right|$ & 0.032 & 0.019 & 0.292 & $2.1 \mathrm{E}-05$ & 3364.4 & -10.69 & 456.1 \\
\hline EXR & $3.0 \mathrm{E}-05$ & 0.000 & 0.031 & -0.027 & 282.37 & -33.07 & 26.84 \\
\hline $\mathrm{D}^{\text {up }}$ & 0.563 & 1.000 & 1.000 & 0.000 & 174.68 & -31.10 & 49.81 \\
\hline$D^{\text {bullish }}$ & 0.195 & 0.000 & 1.000 & 0.000 & 421.80 & -1.79 & 18512 \\
\hline $\mathrm{D}^{\text {crises }}$ & 0.219 & 0.000 & 1.000 & 0.000 & 322.13 & -1.70 & 18709 \\
\hline $\mathrm{D}^{\text {volatility }}$ & 0.383 & 0.000 & 1.000 & 0.000 & 176.84 & -6.73 & 4887 \\
\hline
\end{tabular}

Notes:

1. JB is the Jarque-Bera test statistic for normality. Under null hypothesis for normality, critical value of $\chi^{2}$ (2) distribution at $5 \%$ significance level is 5.99 .

2. ADF is the Augmented Dickey-Fuller test statistic for stationarity of data for maximum 21 lags. Under null hypothesis for data having unit root, the critical value at $5 \%$ significance level is -2.87 .

3. Q (20) is the Ljung-Box Q statistic for serial correlation upto20 lags. Under the null hypothesis for no serial correlation, the critical value of $\chi 2$ (20) distribution at $5 \%$ significance level is 31.41 .

As Table 1 reports, all regression variables including the distribution of CSAD are highly nonnormal, as JB test statistic substantially exceeds the critical value of 5.99 at 5 percent significance level. Certain variables such as absolute market return and dummy variables are usually nonnormal, as their values are generated from specific computations. The descriptive statistics of these sample data are reported for readers who understand the nature of their distributions. Except for bullish and crisis dummy variables, all other variables are highly stationary. The ADF test statistic substantially exceeds the critical value of -2.87 for these variables. However, variables such as $C A S D_{p}^{F U N D}$, returns on GSCI gold, and oil indices and exchange rate return data are serially uncorrelated, as null hypothesis for no serial correlation up to 20 lags is accepted under the Ljung-Box Q test. Other variables are highly serially correlated. 

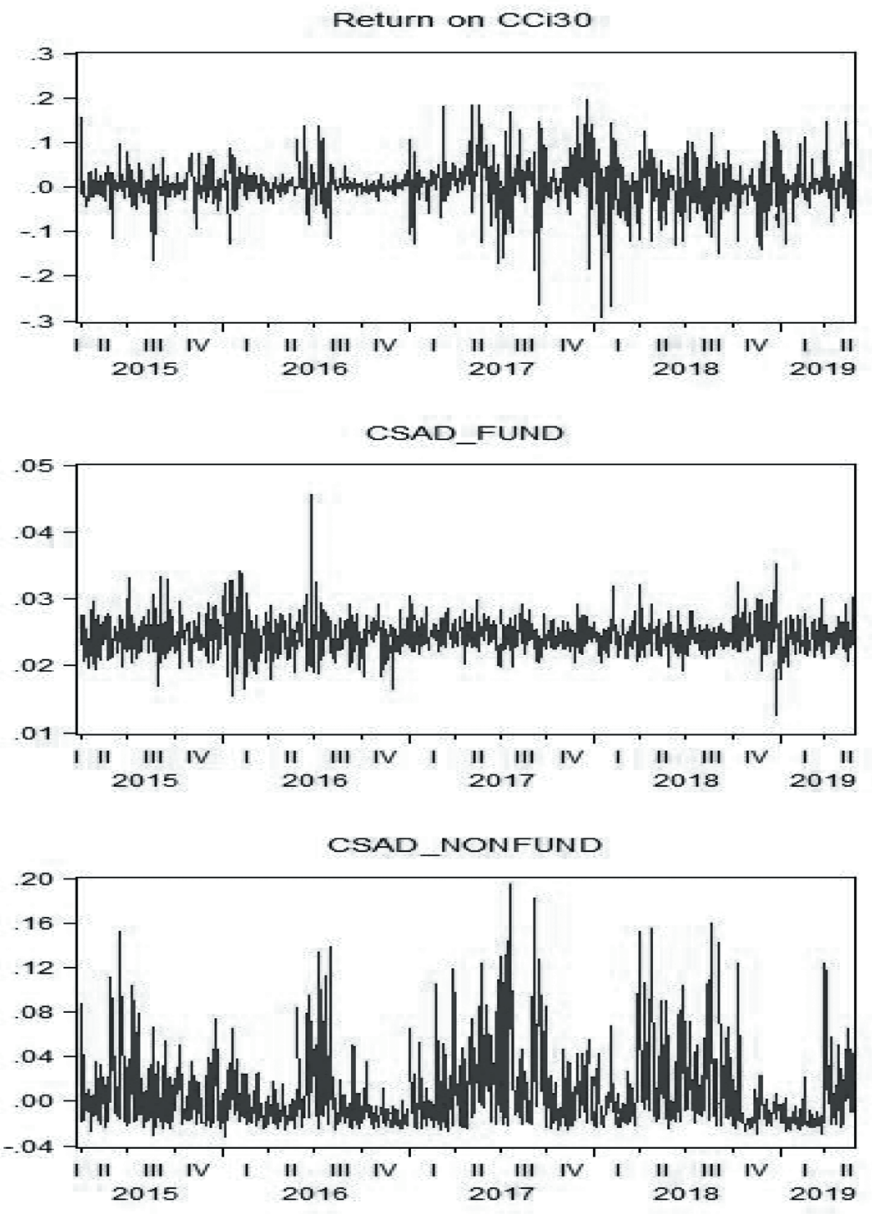

As Figure 1 exhibits, CCi30 index return is highly volatile during 2017 and 2018. This period is characterized by the largest cluster of price changes in the history of cryptocurrency trading. CSAD driven by fundamental information seems to fluctuate somewhat during 2015 and 2016. No significant variation in CSAD driven by fundamental information is observed from 2017 to 2018, although a significant variation in market return (i.e., CCi30 index return) can be observed during this period. This provides an indication as to whether the herding during bullish and crisis periods (i.e., 2017-2018) was not driven by fundamental information pertaining to cryptocurrency price changes. Furthermore, non-fundamental CSAD is highly variable from 2017 to 2018, and seems to correlate somewhat with CCi30 index return. However, a conclusion on the above can only be reached based on the results of herding regression specifications outlined above.

\section{Empirical Findings}

As Table 3 outlines, US equity risk premium, cryptocurrency market return, and US/Euro exchange rate return are not significant for explaining CSAD. However, GSCI index for oil and gold are significant in the regression equation (5) at 10 percent significance level. 
Numerous papers show that the cryptocurrency returns are not correlated with macro/microeconomic variables; thus, exhibiting a speculative nature of price changes. The scholars have argued that it provides significant diversification benefits (see, e.g., Briere et al., 2015; Baur et al., 2018) based on the assessment of correlation between cryptocurrency and other speculative assets. However, CSAD is shown to provide some predictive power of GSCI oil and gold commodity index returns. ARCH and GARCH coefficients are highly statistically significant at $5 \%$ significance level. The sum of $\pi$ and $\lambda$ is less than unity, indicating a good fit for the underlying return series volatility process. Since the leverage effect is not observed in the cryptocurrency market for the considered period, the GARCH $(1,1)$ model more preciously captures the time-varying volatility.

Table 3 - CSAD Regression Results

\begin{tabular}{|c|c|c|c|}
\hline \multicolumn{4}{|c|}{$C S A D_{p t}=\phi+\psi_{1} R P_{t}^{U S}+\psi_{2} G S C I_{t}^{o I L}+\psi_{3} G S C I_{t}^{G O L D}+\psi_{4} C C i 30_{t}+\psi_{5} E X R_{t}+\varepsilon_{t}$} \\
\hline Coefficient & Value & $t$-statistic & $P$-value \\
\hline$\phi$ & $0.024^{\star \star}$ & 27.85 & 0.000 \\
\hline$\psi_{1}$ & -0.104 & -1.051 & 0.293 \\
\hline$\psi_{2}$ & $-0.071^{\star}$ & -1.874 & 0.061 \\
\hline$\psi_{3}$ & $0.200^{*}$ & 1.800 & 0.072 \\
\hline$\psi_{4}$ & 0.013 & 0.455 & 0.649 \\
\hline$\psi_{5}$ & -0.171 & -0.859 & 0.391 \\
\hline$a$ & $5.6 \mathrm{E}-05^{\star *}$ & 2.835 & 0.005 \\
\hline$\pi$ & $0.176^{\star *}$ & 3.573 & 0.000 \\
\hline$\lambda$ & $0.792^{\star *}$ & 17.124 & 0.000 \\
\hline
\end{tabular}

1. ${ }^{*}$ Statistically significant at 5 percent, assuming returns are conditionally normally distributed. ${ }^{\star}$ Statistically significant at 10 percent.

2. The coefficients are estimated using the methods described by Bollerslev and Wooldridge (1992) for obtaining quasi-maximum likelihood (QML) covariances and robust standard errors.

3. Log likelihood is 2154.78 and Durbin-Watson statistic for autocorrelation in the residuals from the regression above is 1.106 and Akaike info criterion for the model is -4.098 .

Table 4 outlines the test results of general herding regressions. The results show that the coefficient $\gamma_{3}$, which captures the herd behaviour of investors (on fundamental information) in the cryptocurrency market, is positive and statistically insignificant at 5 percent significance level. This confirms that there is no evidence for herding on fundamental information (e.g., information regarding economic policy uncertainty, financial and economic crisis, economic innovation, regularity formwork, economic growth, IT sector innovations, etc.) in the cryptocurrency market during the sampling period. Herding on fundamental information generally results in inefficient market conditions (Bikhchandani and Sharma 2000). However, there is a tendency to herd on non-fundamental information as coefficient $\gamma_{3}$ is negative and statistically significant at 1 percent significance level. This non-fundamental information may include information concerning cryptocurrency trading itself, for example, ICO project, trading restrictions, system failures such as hacking, frauds, trading suspension, or restrictions on cash withdrawal, etc. Concerning stock markets, Kremer and Nautz, (2013, p. 1) argue that unintentional herding can sometimes be inefficient if the trading is not driven by fundamental values. 
Unlike assets trading in other markets, there are no underlying assets for cryptocurrency trading. Therefore, there is no meaningful information flow that reflects the true value of underlying cryptocurrencies. As such, the cryptocurrency price changes can be pseudo-efficient based on the findings above. These findings do not suggest that traditional assets could be diversified with cryptocurrencies simply on the basis of correlation (e.g., low correlation) between cryptocurrencies and traditional assets. If diversified, care must be taken in periodically evaluating the investment portfolio for possible underestimation of true risk associated with cryptocurrency investments (See Šoja and Senarathne 2019).

Table 4-General Herding Regression Results

\begin{tabular}{|c|c|c|c|c|c|c|c|c|}
\hline \multirow{2}{*}{$\begin{array}{c}\text { Dep. } \\
\text { Variable }\end{array}$} & \multicolumn{8}{|c|}{$C S A D_{t}=a+\gamma_{1} R_{c c i 30 t}+\gamma_{2}\left|R_{c c i 30 t}\right|+\gamma_{3} R_{c c i 30 t}^{2} u_{t}$} \\
\hline & $\gamma_{1}$ & $\gamma_{2}$ & $\gamma_{3}$ & $\pi$ & $\lambda$ & AIK & $\mathrm{DW}^{4}$ & $\log \mathrm{L}$ \\
\hline$C S A D_{p t}^{F U N D}$ & $\begin{array}{l}0.012^{*} \\
(9.355)\end{array}$ & $\begin{array}{c}0.004 \\
(0.800)\end{array}$ & $\begin{array}{c}0.003 \\
(0.114)\end{array}$ & $\begin{array}{l}0.152^{*} \\
(3.371)\end{array}$ & $\begin{array}{l}0.809^{*} \\
(20.25)\end{array}$ & -9.26 & 2.15 & 4854 \\
\hline$C S A D_{p t}^{N O N F U N D}$ & $\begin{array}{c}0.013 \\
(0.510)\end{array}$ & $\begin{array}{l}0.490^{\star} \\
(8.182)\end{array}$ & $\begin{array}{l}-1.217^{\star} \\
(-3.232)\end{array}$ & $\begin{array}{l}0.193^{\star} \\
(4.170)\end{array}$ & $\begin{array}{c}0.765^{\star} \\
(13.79)\end{array}$ & -4.30 & 1.23 & 2256 \\
\hline
\end{tabular}

Notes:

1. Asymptotic t-statistic appears in parenthesis.

2. ${ }^{*}$ Statistically significant at 1 percent, assuming returns are conditionally normally distributed.

3. The coefficients are estimated using the methods described by Bollerslev and Wooldridge (1992) for obtaining quasi-maximum likelihood (QML) covariances and robust standard errors.

4. DW is the Durbin-Watson statistic for autocorrelation in the residuals from the respective regression. Field (2000)'s rule of thumb suggests that values under 1 or more than 3 are a definite cause for concern and any value within the rage is acceptable.

5. LogL is the Log likelihood value and AIK is the Akaike info criterion.

Table 5 reports the herding regression test results under different market conditions. Equations 10 and 11 estimate the impact of herding under up-trending market and other than upward-trending market conditions during the sampling period. Using logistic regression techniques, Bouri et al. (2018b) find evidence for significant herding when uncertainty increases. Therefore, it is likely that herding may be more intensive under extreme market conditions. More importantly, Vidal-Tomás et al. (2018) find evidence for herding only during down-trending markets. However, the findings of this study show that the cryptocurrency market is characterised by herding during down-trending and upward-trending mark conditions on non-fundamental information, as coefficients $\gamma_{3}$ and $\gamma_{4}$ are negative and highly statistically significant at 1 percent significance level. Herding on non-fundamental information does not indicate inefficient conditions in the cryptocurrency market, although herding on fundamental information does. Given the lack of intrinsic value of cryptocurrency, this form of herding can lead to pseudo-efficient conditions as opposed to the market-efficiency concept put forward by Fama (1965) and many of his successors (see, e.g., Tobin 1984; Roll 1988). There is no evidence for the presence of herding during other market conditions (bullish, crisis, and high market volatility) under fundamental and non-fundamental CSAD regressions, as coefficients $\gamma_{3}$ and $\gamma_{4}$ are not negative, although some coefficients are significant. 
Table 5 Herding under Market Conditions

\begin{tabular}{|c|c|c|c|c|c|c|c|c|c|c|}
\hline Equ. & Dep. Var. & $\gamma_{1}$ & $\gamma_{2}$ & $\gamma_{3}$ & $\gamma_{4}$ & $\pi$ & $\lambda$ & AIK & DW4 & $\log L$ \\
\hline \multirow{2}{*}{$\begin{array}{c}10 \& \\
11\end{array}$} & $C S A D_{p t}^{F U N D}$ & $\begin{array}{l}0.009^{*} \\
(1.687)\end{array}$ & $\begin{array}{l}0.017^{\star *} \\
(3.225)\end{array}$ & $\begin{array}{c}0.006 \\
(0.189) \\
\end{array}$ & $\begin{array}{c}-0.012 \\
(-0.325)\end{array}$ & $\begin{array}{l}0.153^{\star *} \\
(3.375)\end{array}$ & $\begin{array}{l}0.808^{\star *} \\
(20.15)\end{array}$ & -9.28 & 2.14 & 4855 \\
\hline & $C S A D_{p t}^{N O N F U N D}$ & $\begin{array}{l}-0.463^{\star *} \\
(-6.203)\end{array}$ & $\begin{array}{l}0.563^{\star *} \\
(6.717) \\
\end{array}$ & $\begin{array}{l}-1.096^{* *} \\
(-2.492)\end{array}$ & $\begin{array}{l}-1.792^{\star *} \\
(-2.503)\end{array}$ & $\begin{array}{l}0.197^{\star \star} \\
(4.217)\end{array}$ & $\begin{array}{l}0.762^{\star *} \\
(13.77)\end{array}$ & -4.29 & 1.23 & 2257 \\
\hline \multirow{2}{*}{$\begin{array}{c}12 \& \\
13\end{array}$} & $C S A D_{p t}^{F U N D}$ & $\begin{array}{l}0.014^{\star \star} \\
(7.495)\end{array}$ & $\begin{array}{l}0.012^{* *} \\
(6.962)\end{array}$ & $\begin{array}{l}0.033^{\star \star} \\
(2.002)\end{array}$ & $\begin{array}{c}0.008 \\
(0.740) \\
\end{array}$ & $\begin{array}{l}0.153^{\star \star} \\
(3.312)\end{array}$ & $\begin{array}{l}0.807^{\star \star} \\
(19.63)\end{array}$ & -9.27 & 2.15 & 4855 \\
\hline & $C S A D_{p t}^{N O N F U N D}$ & $\begin{array}{l}0.048^{*} \\
(1.752)\end{array}$ & $\begin{array}{c}-0.006 \\
(-0.113)\end{array}$ & $\begin{array}{l}1.240^{\star *} \\
(4.450)\end{array}$ & $\begin{array}{l}2.258^{\star *} \\
(5.907)\end{array}$ & $\begin{array}{l}0.160^{\star *} \\
(4.359)\end{array}$ & $\begin{array}{l}0.819^{\star *} \\
(22.17)\end{array}$ & -4.22 & 1.21 & 2217 \\
\hline \multirow{2}{*}{$\begin{array}{c}14 \& \\
15\end{array}$} & $C S A D_{p t}^{F U N D}$ & $\begin{array}{l}0.013^{\star *} \\
(8.548)\end{array}$ & $\begin{array}{l}0.012^{\star *} \\
(4.306)\end{array}$ & $\begin{array}{l}0.019^{*} \\
(1.910)\end{array}$ & $\begin{array}{c}0.020 \\
(0.983) \\
\end{array}$ & $\begin{array}{l}0.152^{\star *} \\
(3.354)\end{array}$ & $\begin{array}{l}0.810^{\star *} \\
(20.27)\end{array}$ & -9.26 & 2.15 & 4854 \\
\hline & $C S A D_{p t}^{N O N F U N D}$ & $\begin{array}{c}0.030 \\
(1.081)\end{array}$ & $\begin{array}{c}-0.010 \\
(-0.248)\end{array}$ & $\begin{array}{l}2.266^{\star *} \\
(9.067)\end{array}$ & $\begin{array}{l}0.771^{\star *} \\
(2.681)\end{array}$ & $\begin{array}{l}0.160^{\star *} \\
(4.397)\end{array}$ & $\begin{array}{l}0.822^{* *} \\
(22.33)\end{array}$ & -4.24 & 1.21 & 2227 \\
\hline \multirow{2}{*}{$\begin{array}{c}17 \& \\
18\end{array}$} & $C S A D_{p t}^{F U N D}$ & $\begin{array}{l}0.013^{\star *} \\
(5.904)\end{array}$ & $\begin{array}{l}0.012^{\star *} \\
(7.053) \\
\end{array}$ & $\begin{array}{l}0.041^{\star *} \\
(1.999)\end{array}$ & $\begin{array}{c}0.017 \\
(1.354) \\
\end{array}$ & $\begin{array}{l}0.153^{\star *} \\
(3.368)\end{array}$ & $\begin{array}{l}0.809^{\star *} \\
(20.37)\end{array}$ & -9.26 & 2.15 & 4856 \\
\hline & $C S A D_{p t}^{N O N F U N D}$ & $\begin{array}{c}0.021 \\
(0.481)\end{array}$ & $\begin{array}{l}0.047^{\star} \\
(1.840)\end{array}$ & $\begin{array}{l}3.032^{\star *} \\
(6.998)\end{array}$ & $\begin{array}{l}0.982^{\star *} \\
(4.538)\end{array}$ & $\begin{array}{l}0.167^{\star *} \\
(4.655)\end{array}$ & $\begin{array}{l}0.814^{\star *} \\
(22.32)\end{array}$ & -4.26 & 1.15 & 2236 \\
\hline
\end{tabular}

Note:

1. Asymptotic t-statistic appears in parenthesis.

2. ${ }^{*}$ Statistically significant at 5 percent assuming returns are conditionally normally distributed. ${ }^{\star}$ Statistically significant at 10 percent

3. The coefficients are estimated using the methods described by Bollerslev and Wooldridge (1992) for obtaining quasi-maximum likelihood (QML) covariances and robust standard errors.

4. DW is the Durbin-Watson statistic for autocorrelation in the residuals from the respective regression. Field (2000)'s rule of thumb suggests that values under 1 or more than 3 are a definite cause for concern and any value within the rage is acceptable.

5. $\log \mathrm{L}$ is the Log likelihood value.

\section{CONCLUDING REMARKS}

The notion of herding was first rooted in zoology before it had been widely used in sociology, psychology, economics, and finance. It is the act of bringing individual animals together into a group and maintaining or moving the group from place to another; where the herder directs the animals (the animals need not worry about where they go). However, there is no-one to direct investors in speculative markets (e.g., cotton futures, stock markets, oil and gold, etc.); instead, the investors are directed by the information they have received. As such, investor herding in speculative markets can only be identified with reference to the information pertaining to underlying assets (e.g., firms).

The initial regression results show that the CSAD can only be explained by GSCI oil and gold index return. No relationship exists between CSAD and other variables such as return on CCi30, US equity risk premium, and US/Euro exchange rate return. These findings are in line with the observations of Baur and Lucey (2010), Briere et al. (2015) and Baur et al. (2018), in that for return on stocks, exchanges rates are uncorrelated with cryptocurrency returns. ${ }^{3}$

3 These studies examine the relationship between cryptocurrency return and return on other speculative variables such stocks, exchange rates, oil and gold. However this study finds that CSAD can be explained by the GSCI oil and gold index returns. 
The herding regression under normal market (i.e., general market) conditions shows that a strong tendency exists to herd on non-fundamental information that explains CSAD of returns. This clearly indicates the speculative nature of cryptocurrency price changes, and supports the argument that cryptocurrency returns cannot be predicted on the basis of fundamental economic information (e.g., major macroeconomic announcements), as documented by a number of scholars. Furthermore, herding regression under different market conditions reveals that herding on non-fundamental information in the cryptocurrency market is more pronounced during an upward-trending market and other than upward-trending market periods. No evidence for herding on fundamental information could be observed under normal or other market conditions (e.g., bullish, crisis, high volatility).

The findings of this research have several implications for future research. Although the cryptocurrency market may be efficient at the pricing stage, as shown by numerous papers, herding on non-fundamental information suggests that the trading is functionally efficient. However, this form of efficiency does not reflect the true underlying security-specific information (e.g., firm-specific information in the case of stock market) in the absence of underlying assets (i.e., lack of intrinsic value) in the cryptocurrency trading platform. As such, cryptocurrency can be regarded as a pseudo-efficient instrument for speculative exchange traders. Previous research on market efficiency must be revisited to research the behavioural factors affecting cryptocurrency price changes. These findings do not suggest that traditional assets could be diversified with cryptocurrency simply on the basis of correlation (i.e., low correlation) between cryptocurrencies and traditional assets. Furthermore, the findings are important for investors and portfolio managers to understand the market dynamics and the role of cryptocurrency in portfolio diversification.

\section{ACKNOWLEDGMENT}

The author would like to thank the Editor-in-chief, Nemanja Stanišić, the Managing Editor, Gordana Dobrijević and the editorial board. Useful comments from three anonymous reviewers shall be gratefully acknowledged. Usual disclaimer applies.

\section{REFERENCES}

Avery, C., \& Zemsky, P. (1998). Multidimensional uncertainty and herd behavior in financial markets. The American Economic Review, 88(4), 724-748.

Baek, C., \& Elbeck, M. (2015). Bitcoins as an investment or speculative vehicle? A first look. Applied Economics Letters, 22(1), 30-34. DOI: https://doi.org/10.1080/13504851.2014.916379.

Balcilar, M., Demirer, R., \& Hammoudeh, S. (2013). Investor herds and regime-switching: Evidence from Gulf Arab stock markets. Journal of International Financial Markets, Institutions and Money, 23, 295-321. DOI: https://doi.org/10.1016/j.intfin.2012.09.007.

Baur, D. G., \& Lucey, B. M. (2010). Is gold a hedge or a safe haven? An analysis of stocks, bonds and gold. Financial Review, 45(2), 217-229. DOI: https://doi.org/10.1111/j.1540-6288.2010.00244.x.

Baur, D. G., Dimpfl, T., \& Kuck, K. (2018a). Bitcoin, gold and the US dollar-A replication and extension. Finance Research Letters, 25, 103-110. DOI: https://doi.org/10.1016/j.frl.2017.10.012.

Baur, D. G., Hong, K., \& Lee, A. D. (2017). Bitcoin: Medium of exchange or speculative assets?. Journal of International Financial Markets, Institutions and Money, 54, 177-189. DOI: https://doi.org/10.1016/j. intfin.2017.12.004. 
Bekiros, S., Jlassi, M., Lucey, B., Naoui, K., \& Uddin, G. S. (2017). Herding behavior, market sentiment and volatility: Will the bubble resume?. The North American journal of economics and finance, 42, 107-131. DOI: https://doi.org/10.1016/j.najef.2017.07.005.

BenSaïda, A. (2017). Herding effect on idiosyncratic volatility in US industries. Finance Research Letters, 23, 121-132. DOI: https://doi.org/10.1016/j.frl.2017.03.001.

Bikhchandani, S., \& Sharma, S. (2000). Herd behavior in financial markets. IMF Staff papers, 47(3), 279-310.

Black, F. (1972). Capital market equilibrium with restricted borrowing. The Journal of Business, 45(3), 444-455. DOI: https://doi.org/10.1086/295472.

Bouoiyour, J., \& Selmi, R. (2015). What does Bitcoin look like?. Annals of Economics \& Finance, 16(2), 449-492.

Bouri, E., Gupta, R., \& Roubaud, D. (In Press). Herding behaviour in cryptocurrencies. Finance Research Letters. doi.org/10.1016/j.frl.2018.07.008. DOI: https://doi.org/10.1016/j.frl.2018.07.008.

Bowe, M., and Domuta, D. (2004). Investor herding during financial crisis: A clinical study of the Jakarta Stock Exchange. Pacific-Basin Finance Journal, 12(4), 387-418. DOI: https://doi.org/10.1016/j.pacfin.2003.09.003.

Briere, M., Oosterlinck, K., \& Szafarz, A. (2015). Virtual currency, tangible return: Portfolio diversification with bitcoin. Journal of Asset Management, 16(6), 365-373. DOI: https://doi.org/10.1057/jam.2015.5.

Caporale, G. M., Gil-Alana, L., \& Plastun, A. (2018). Persistence in the cryptocurrency market. Research in International Business and Finance, 46, 141-148. DOI: https://doi.org/10.1016/j.ribaf.2018.01.002.

Chang, E. C., Cheng, J. W., \& Khorana, A. (2000). An examination of herd behavior in equity markets: An international perspective. Journal of Banking \& Finance, 24(10), 1651-1679. DOI: https://doi.org/10.1016/s0378-4266(99)00096-5.

Cheah, E. T., \& Fry, J. (2015). Speculative bubbles in Bitcoin markets? An empirical investigation into the fundamental value of Bitcoin. Economics Letters, 130, 32-36.

Chen, T. (2013). Do investors herd in global stock markets?. Journal of Behavioral Finance, 14(3), 230-239. DOI: https://doi.org/10.1080/15427560.2013.819804.

Chuen, D. L. K., Guo, L., \& Wang, Y. (2017). Cryptocurrency: A new investment opportunity?. The Journal of Alternative Investments, 20(3), 16-40. DOI: https://doi.org/10.3905/jai.2018.20.3.016.

Darrat, A. F., \& Rahman, S. (1995). Has futures trading activity caused stock price volatility?. The Journal of Futures Markets (1986-1998), 15(5), 537. DOI: https://doi.org/10.1002/fut.3990150503.

Demirer, R., \& Kutan, A. M. (2006). Does herding behavior exist in Chinese stock markets?. Journal of international Financial markets, institutions and money, 16(2), 123-142. DOI: https://doi.org/10.1016/j.intfin.2005.01.002.

Demirer, R., Kutan, A. M., \& Chen, C. D. (2010). Do investors herd in emerging stock markets?: Evidence from the Taiwanese market. Journal of Economic Behavior \& Organization, 76(2), 283-295. DOI: https://doi.org/10.1016/j.jebo.2010.06.013.

Dennis, P. J., \& Strickland, D. (2002). Who blinks in volatile markets, individuals or institutions?. The Journal of Finance, 57(5), 1923-1949. DOI: https://doi.org/10.1111/0022-1082.00484.

Dyhrberg, A. H. (2016). Bitcoin, gold and the dollar-A GARCH volatility analysis. Finance Research Letters, 16, 85-92. DOI: https://doi.org/10.1016/j.frl.2015.10.008.

Fama, E. F. (1965). The behavior of stock-market prices. The journal of Business, 38(1), 34-105.

Field, A. (2000). Discovering statistics using SPSS:(and sex, drugs and rock'n'roll) (Vol. 497). Sage.

Froot, K. A., Scharfstein, D. S., \& Stein, J. C. (1992). Herd on the street: Informational inefficiencies in a market with shortterm speculation. The Journal of Finance, 47(4), 1461-1484. DOI: https://doi.org/10.1111/j.1540-6261.1992.tb04665.x.

Gabaix, X., Gopikrishnan, P., Plerou, V., \& Stanley, H. E. (2006). Institutional investors and stock market volatility. The Quarterly Journal of Economics, 121(2), 461-504. DOI: https://doi.org/10.3386/w11722.

Gallo, G. M., \& Pacini, B. (2000). The effects of trading activity on market volatility. The European Journal of Finance, 6(2), 163-175.

Glaser, F., Zimmermann, K., Haferkorn, M., Weber, M. C., \& Siering, M. (2014). Bitcoin-asset or currency? revealing users' hidden intentions. Revealing Users' Hidden Intentions (April 15, 2014). ECIS. 
Gleason, K. C., Mathur, I., \& Peterson, M. A. (2004). Analysis of intraday herding behavior among the sector ETFs. Journal of Empirical Finance, 11(5), 681-694. DOI: https://doi.org/10.1016/j.jempfin.2003.06.003.

Guesmi, K., Saadi, S., Abid, I., \& Ftiti, Z. (2019). Portfolio diversification with virtual currency: Evidence from bitcoin. International Review of Financial Analysis, 63, 431-437. DOI: https://doi.org/10.1016/j.irfa.2018.03.004.

Hirshleifer, D., \& Hong Teoh, S. (2003). Herd behaviour and cascading in capital markets: A review and synthesis. European Financial Management, 9(1), 25-66. DOI: https://doi.org/10.1111/1468-036x.00207.

Holmes, P., Kallinterakis, V., \& Ferreira, M. L. (2013). Herding in a concentrated market: a question of intent. European Financial Management, 19(3), 497-520. DOI: https://doi.org/10.1111/j.1468-036x.2010.00592.x.

Hwang, S., \& Salmon, M. (2004). Market stress and herding. Journal of Empirical Finance, 11(4), 585-616. DOI: https://doi.org/10.1016/j.jempfin.2004.04.003.

Kremer, S., \& Nautz, D. (2013). Causes and consequences of short-term institutional herding. Journal of Banking \& Finance, 37(5), 1676-1686. DOI: https://doi.org/10.1016/j.jbankfin.2012.12.006.

Litimi, H., BenSaïda, A., \& Bouraoui, O. (2016). Herding and excessive risk in the American stock market: A sectoral analysis. Research in International Business and Finance, 38, 6-21. DOI: https://doi.org/10.1016/j.ribaf.2016.03.008.

Nofsinger, J. R., \& Sias, R. W. (1999). Herding and feedback trading by institutional and individual investors. The Journal of Finance, 54(6), 2263-2295. DOI: https://doi.org/10.1111/0022-1082.00188.

Othman, A. H. A., Alhabshi, S. M., \& Haron, R. (2019). The effect of symmetric and asymmetric information on volatility structure of crypto-currency markets: A case study of bitcoin currency. Journal of Financial Economic Policy, DOI: https://doi.org/10.1108/JFEP-10-2018-0147.

Ouarda, M., El Bouri, A., \& Bernard, O. (2013). Herding behavior under markets condition: Empirical evidence on the European financial markets. International Journal of Economics and Financial Issues, 3(1), 214-228.

Peiyuan, S., \& Donghui, S. (2002). CAPM based study of herd behavior: Evidence from Chinese stock market and discussion with Song Jun and Wu Chongfent. Economic Research Journal, 2, 64-70.

Philippas, N., Economou, F., Babalos, V., \& Kostakis, A. (2013). Herding behavior in REITs: Novel tests and the role of financial crisis. International Review of Financial Analysis, 29, 166-174. DOI: https://doi.org/10.1016/j.irfa.2013.01.004.

Poyser, O. (2018). Herding behavior in cryptocurrency markets. arXiv preprint arXiv:1806.11348. Available at https://arxiv.org/pdf/1806.11348.pdf.

Roll, R. (1988). R2. The Journal of Finance, 43(3), 541-566. DOI: https://doi. org/10.1111/j.1540-6261.1988.tb04591.x.

Senarathne, C. W. (2018). Gambling behavior in cryptocurrency market. Working paper, Wuhan University of Technology.

Senarathne, C. W. (2019). The leverage effect and information flow interpretation for speculative Bitcoin prices: Bitcoin volume vs ARCH effect. European Journal of Economic Studies, 8(1), 77-84. DOI: https://doi.org/10.13187/es.2019.1.77.

Senarathne, C. W., \& Jayasinghe, P. (2017). Information flow interpretation of heteroskedasticity for capital asset pricing: An expectation-based view of risk. Economic Issues, 22(1), 1-24.

Senarathne, C. W., \& Jianguo, W. (2018). Do investors mimic trading strategies of foreign investors or the market: Implications for capital asset pricing. Studies in Business and Economics, 13(3), 171-205. DOI: https://doi. org/10.2478/sbe-2018-0042.

Šoja, T., \& Senarathne, C. W. (2019). The Role of Bitcoin in Portfolio Diversification from the Perspective of a Global Investor. Unpublished working paper, Central Bank of Bosnia and Herzegovina.

Tan, L., Chiang, T. C., Mason, J. R., \& Nelling, E. (2008). Herding behavior in Chinese stock markets: An examination of A and B shares. Pacific-Basin Finance Journal, 16(1-2), 61-77. DOI: https://doi.org/10.1016/j.pacfin.2007.04.004.

Tobin, J. (1984). On the efficiency of the financial system. Lloyd's Bank Review, 153, 1-15.

Urquhart, A. (2016). The inefficiency of Bitcoin. Economics Letters, 148, 80-82. DOI: https://doi.org/10.1016/j. econlet.2016.09.019.

Urquhart, A. (2017). The volatility of bitcoin. Available at: https://papers.ssrn.com/sol3/papers.cfm?abstract_id=2921082. van Wijk, D. (2013). What can be expected from the BitCoin. Erasmus Universiteit Rotterdam. Available at https://thesis.eur.nl/pub/14100/Final-version-Thesis-Dennis-van-Wijk.pdf. 
Vidal-Tomás, D., Ibáñez, A. M., \& Farinós, J. E. 2018 (In Press). Herding in the cryptocurrency market: CSSD and CSAD approaches. Finance Research Letters (forthcoming). DOI: https://doi.org/10.1016/j.frl.2018.09.008.

Wei, W. C. (2018). Liquidity and market efficiency in cryptocurrencies. Economics Letters, 168, 1-24. DOI: https://doi.org/10.1016/j.econlet.2018.04.003.

Yao, J., Ma, C. \& He, W. P., (2014). Investor Herding Behaviour of Chinese Stock Market. International Review of Economics and Finance, 29(1), 12-29. DOI: https://doi.org/10.1016/j.iref.2013.03.002.

Yermack, D. (2015). Is Bitcoin a real currency? An economic appraisal. Handbook of Digital Currency. pp. 31-43. DOI: https://doi.org/10.1016/b978-0-12-802117-0.00002-3. 


\section{PONAŠANJE GOMILE NA TRŽIŠTU KRIPTOVALUTE: STVARNO VS LAŽNO GOMILANJE}

\section{Rezime:}

Ovaj rad ima za cilj da istraži da li gomilanje investitora, na tržištu kriptovalute, dovodi do korelacije u prinosu kriptovalute - uz upotrebu metodologije Čenga i dr, Galariotisa i dr, a na primeru uzorka podataka u vremenskom okviru 30.03.2015-24.05.2019. Početni rezultati regresije ukazuju na to da apsolutna, standardna devijacija širokog spektra u prinosu može biti objašnjena samo indeksom prinosa GSCI ulja i zlata, kao i da ne postoji spona između apsolutne standardne devijacije širokog spektra i drugih varijabli regresije, poput prinosa u vezi sa Cci30, premije za tržišni rizik SAD-a, kao i prinosa koji se odnosi na kurs američkog dolara ili Evra. Rezultati regresije gomilanja - u standardnim uslovima tržišta, pokazuju da postoji izražena sklonost gomilanja na ne-fundamentalnim informacijama, što objašnjava apsolutnu standardnu devijaciju prinosa širokog sprektra. Kao takvi, prinosi kriptovalute ne mogu da se predvide, a na osnovu fundamentalnih, stvarnih informacija, relevantnih za ekonomiju (npr. značajne objave na makroekonomskom planu). Gomilanje zasnovano na informacijama koje nisu fundamentalne učestalije je, kako je primećeno, tokom perioda rasta na tržištu, dok ovakve vrste gomilanja nema u drugačijim okolnostima na tržištu. Premda teorija sugeriše da gomilanje zasnovano na infomacijama koje nisu od fundamentalne vrednosti dovodi do efikasnijih ishoda, prethodno izloženo ne govori u prilog diversifikacije tradicionalnih sredstava kriptovalutom, na osnovu slabe korelacije. Budući da kriptovaluti nedostaje intrinzična vrednost, takva razmena dovodi do nastanka pseudo-efikasne platforme za trgovinu spekulativnih investitora. Na kraju rada, navode se implikacije u vezi sa budućim istraživanjem.
Ključne reči:

ponašanje gomile, kriptovaluta, fundamentalne informacije,

CASD, portfolio diversfikacija, pseudo-efikasnost, intrinzična vrednost.

\section{JEL Classification:}

G15, G14 